\title{
INTERPRETING THE NARRATIVES OF MĀORI ENTREPRENEURS
}

\author{
Jess Nandu-Templeton* \\ Mark Vanderklei ${ }^{\dagger}$ \\ Herb de Vries ${ }^{\ddagger}$ \\ Tyron Love ${ }^{\S}$ \\ Robert Hamilton"
}

\begin{abstract}
A growing body of research within the realm of Māori entrepreneurship is being produced by researchers offering powerful alternatives to Western hegemonic academic discourses. Ethnic minority research has also sought to challenge the West's construction of entrepreneurship and its lack of plurivocality, yet few entrepreneurship models have embraced intersecting theory. We think that this oversight presents a useful opportunity for enhancing the study of Māori entrepreneurship in Aotearoa New Zealand. We take up this opportunity by identifying a framework for theorising Māori entrepreneurship in the future built on (a) an established embeddedness model, (b) the work of a diverse research team employing a Kaupapa Māori methodology, and (c) empirical insights from Māori entrepreneurs.
\end{abstract}

* Tainui. Doctoral Candidate, University of Canterbury, Christchurch, New Zealand.

† Tainui and Ngātiwai. Doctoral Candidate, University of Canterbury, Christchurch, New Zealand.

‡ Senior Lecturer, Department of Management, Marketing and Entrepreneurship, University of Canterbury, Christchurch, New Zealand.

$\S$ Te Ātiawa. Associate Dean Māori and Senior Lecturer, Department of Management, Marketing and Entrepreneurship, University of Canterbury, Christchurch, New Zealand. Email: tyron.love@canterbury.ac.nz

Emeritus Professor of Management, University of Canterbury, Christchurch, New Zealand.

DOI: 10.20507/MAIJournal.2017.6.2.6 


\section{Keywords}

Māori, entrepreneurship, collaboration, ethnic minority, embeddedness, narrative, Kaupapa Māori

\section{Introduction}

For some time now writers have commented on the dual purposes of Māori business and entrepreneurship: the intention to straddle or operate in both Māori and Pākehā worlds. A number of authors have sustained the notion that the traditional Māori world is one of affection, whereas the Pākehā is one of exploitation (see, e.g., Henry \& Pene, 2001). Such a contrast brings to light the difficulties in managing Māori enterprises. A Māori enterprise is probably best described as one that "deliberately revolves around Māori people, Māori assets, and Māori priorities” (Durie, 2003, p. 246). As Durie (2003) maintains, "often there appears to be no difference between non-Māori and Māori businesses” (p. 246), but the connection to traditional values, as well as commonly held ways of engaging in the sale of goods and services, appears to be of utmost importance.

According to Mataira (2000), Māori entrepreneurship includes "bicultural pioneers who walk between distinct yet intricately woven worlds of strategic business decisions, tribal politics [and] family politics" (p. 276). As such, it has a broader cultural appeal beyond the market and the commercialisation of products: entrepreneurship "offers the leverage for Māori development and the delivery of opportunities to Māori” (Warriner, 2007, p. 559). Māori researchers and writers contend that entrepreneurial responsibilities spread beyond the boundaries of the immediate commercial entity. History has an important role to play in the contemporary operationalisation of Māori entrepreneurship. The reclaiming of Māori culture has disrupted the social and economic conditions in New Zealand and made way for new forms of enterprise to emerge in response.
Multilayer social enterprise models have proved popular amongst Māori entrepreneurs, and academics have captured the interactions and processes by which opportunistic behaviour may be balanced by kin-accountability (see Tapsell \& Woods, 2008).

In Ella Henry's (2007) view, a form of entrepreneurship in Aotearoa New Zealand connected to traditional Māori values is Kaupapa Māori entrepreneurship. This form is more akin to social entrepreneurship-business activity "underpinned by social objectives to improve wealth and well-being for the community, rather than just the individual" (p. 542). She makes the additional point that "entrepreneurs operate in an environment of risk, and require the flexibility to capitalise on opportunities and develop new innovations, without being hamstrung by community decision-making processes and shared ownership of resources” (Henry, 2007, p. 543).

Historical stories make their way into the contemporary literature on Māori entrepreneurship in powerful and commanding ways. For example, in their paper on "Mauipreneurship", Keelan and Woods (2006) offer an account of Māori entrepreneurship, drawing on the historical stories of the mythical ancestor Māui. Similarly, Tapsell and Woods (2008) use a traditional check and balance model to describe the extent to which Māori enterprises aspire for economic and social outcomes. While traditional ancestral and mythological narratives have been promoted in recent years to encourage more Māori entrepreneurial behaviour (Keelan \& Woods, 2006), the voices of descendant or present-day Māori entrepreneurs seldom make their way into research commentaries. As a consequence, the strategies for exploring or analysing those voices have rarely been 
offered or debated amidst the research. The development of business and social models in other areas of entrepreneurship yields several methodological possibilities for unlocking/ analysing a broader understanding of Māori entrepreneurship.

We believe one such approach-which considers the impact of different embeddedness (see below) constructs as antecedents of entrepreneurship originally developed in the area of ethnic minority group (EMG) entrepreneurship by de Vries, Hamilton and Voges (2015)holds some promise. We have subsequently employed a collaborative approach to exploring embeddedness characteristics. Our research team consists of two researchers who created the original model (de Vries and Hamilton) and three Māori researchers with an interest in this area (Nandu-Templeton, Vanderklei and Love). The aims of this paper are to document our collaboration, assess the relevance of embeddedness as an analytical tool for uncovering meaning behind experiential narratives of present-day Māori entrepreneurs, and highlight the variability of social and cultural context in order to lay the foundations for a contemporary model for empirical exploration and future theorising.

\section{Ethnic minority group research and embeddedness}

The EMG literature seeks to prioritise specific groups-with particular histories, cultures, characteristics and traits-that have been written out of broader discussions on entrepreneurship. The research in this space recognises the plurality of voices that exist within broader multicultural societies. Researchers have argued that EMGs have a cultural propensity towards entrepreneurship (Basu \& Altinay, 2002), that there is a positive relationship between EMGs and the contribution to their host country (Duncan, Bollard, \& Yeabsley, 1997; North \& Trlin, 2004; Yeabsley, 1997), and that there are certain favourable predisposing EMG characteristics such as selective migration, culture, attitude, actions and conditions (Aldrich \& Waldinger, 1990).

Some EMGs are said to fall into entrepreneurship due to disadvantage factors such as specific cultural features and discrimination in paid employment (Clark \& Drinkwater, 2010; Light, 1979). It has been noted, in practice, that entrepreneurship may be a more economically viable option for EMGs who are not willing to accept lower wages because of their migratory status (Cain \& Spoonley, 2013; Light \& Bonacich, 1988). Researchers have drawn a strong connection between rates of entrepreneurship and EMG social and economic performance (Hiebert, 2003; Ram, 1997; Zhou, 2004). Self-employment may also improve the likelihood of intergenerational benefits being realised, such as more money for better educational and recreational opportunities, which exposes the next generations to more valuable networks (Sanders \& Nee, 1996).

Embeddedness has emerged as a unifying construct for understanding differences in EMG behaviours and levels of entrepreneurial activity. The construct was first proposed by Granovetter (1985), who argued that behaviour and institutions are so interlinked with ongoing social relations that to construe them as independent would be a grievous misunderstanding, and that actions are embedded in concrete, ongoing systems of social relations. To this end embeddedness asks how social and economic activities become interwoven with networks of social relations (Krippner et al., 2004). More recently, Wang and Altinay (2012) have argued that "embeddedness reflects the extent the entrepreneur becomes part of the opportunity structure and being embedded actually creates opportunities" (p. 8). But social embeddedness is not a full explanation (Barrett, Jones, McEvoy, \& McGoldrick, 2002; Peters, 2002), and subsequently the concept of mixed embeddedness has been advanced as the meshing of a group's socioeconomic resource profile with 
an opportunity structure that reflects prevailing economic and sociopolitical realities (Jones \& Ram, 2007; Kloosterman, 2010; Kloosterman, van de Leun, \& Rath, 1999; Virdee, 2006).

Aside from its nature, the extent of embeddedness remains elusive, relying much more on researchers' judgements than their ability to measure (Krippner et al., 2004; Wang \& Altinay, 2012). Furthermore, Peters (2002) critiques the mixed embeddedness approach as lacking a historical perspective and catering inadequately for the variability of human agency that ultimately sparks individual entrepreneurship. This points to how an individual's processing of available information mediates the effects of the environment on their behaviour (Ajzen, 1991; de Vries et al., 2015). Therefore an entrepreneur's decisions and actions can be influenced by beliefs about self (e.g., Bandura, 1982, 1991), cultural disposition (e.g., Pantouvakis, 2013; Pio \& Dana, 2014), and trying to make sense of their environment (e.g., Mills \& Pawson, 2006; Nicholson \& Wong, 2001). These concepts have implications for our understanding of Māori entrepreneurship. For example, Tapsell and Woods (2008) explain how the interaction between a rangatira and a pōtiki catalyses innovative enterprise, with the rangatira's guidance-hinged on historic grievances, kin-accountability and traditional hierarchy-balancing the individualistic, commercial disposition of the pōtiki.

In their paper "Antecedents of Ethnic Minority Entrepreneurship in New Zealand: An Inter-group Comparison", de Vries et al. (2015) expand the notion of embeddedness by proposing four continua/constructs which they employ in making comparisons between four different minority ethnic groups operating enterprises in New Zealand: Dutch, Chinese, Indian and Pacific peoples. Those constructs are summarised below:

1. The migration construct is about how and why homeland influences, such as geographic origin, cultural and religious values, language, and personal connection, influence whether a group embeds in preor post-migration traditions.

2. The settlement construct captures the influence of societal and employment fit on integration, and determines whether an EMG embeds in its ethnic or its host community.

3. The identity construct shows different skills and business capabilities and affects whether groups embed either in a singular identity or in a dual ethnic/host identity.

4. The business construct is how the individual agency factors of confidence, and other human and financial capitals, produce a business-ready orientation that can embed in the host country's opportunity structures and spawn entrepreneurship.

We believe the notion of embeddedness that underpins these constructs, as opposed to the constructs per se, holds some promise for interpreting Māori entrepreneurial activity. We do, importantly, recognise the problematic nature of our project in borrowing non-Indigenous constructs as the foundation for our research. However, it is our empirical work that drives our claims in this paper. Given the context within which they were developed, we set out to explore the relevance of the constructs empirically by engaging in Kaupapa Māori research. We uncover how Māori entrepreneurs cast themselves and others in the entrepreneurial space in order to inform a suitable tool for further exploration.

\section{A Kaupapa Māori approach}

Our research team was based at the University of Canterbury-Te Whare Wananga o Waitaha in Ōtautahi (Christchurch), Aotearoa New Zealand. Our research team has Māori tribal affiliations to Tainui (J. T., M. V.), Ngātiwai (M. V.) and Te Ātiawa (T. L.). All team members have diverse Pākehā ancestry. As part of 
this research, two of our researchers (J. T., M. V.) engaged with five Māori entrepreneurs to seek insights into their everyday lives. The approach to engagement was informed by a set of protocols premised on the notion of respect and positive relationships between Māori entrepreneurs as tangata whenua and the research team as manuwhiri customarily observed in the pōwhiri process (McClintock, Mellsop, Moeke-Maxwell, \& Merry, 2010). Primary data were collected through face-to-face semistructured conversations/interviews that were audio-recorded.

We began with a process similar to the karanga; a physical call of invitation. This call was initially addressed to Māori entrepreneurs identified within the researchers' and participants' extended networks; snowball sampling was employed thereafter. Initial introductions were made over the phone and participants who were interested in participating were sent an information brief that introduced each of the researchers and the intent and purpose of the project. Upon acceptance of the brief, a time was scheduled with the participant and a place of their choosing was decided upon for an initial interview. Participants were made aware that they had the right to accept or decline our request to engage with them, based on the information we provided them.

In most cases participants chose to meet in their workplace and in some instances this was also their home. At this mihimihi stage we made formal introductory connections, acknowledged the reason for meeting and clarified the purpose, scope and expectations of the study. It was important that the participants understood they were partners in the research. Therefore, we used an iterative and collaborative approach with the participants, who were viewed as co-creators of knowledge. Consultation, transparency and collaboration were fundamental to whakawhanaungatanga. This involves taking responsibility for connections made with others (Kuntz, Nāswall, Beckingsale, \& Macfarlane, 2014) and is necessary for successful research with Māori. Our mihimihi with participants involved sharing links to whānau, whenua and whakapapa.

At this stage of the interview process, information was exchanged through respectful listening and discussion around the following prompts:

- Tell us about yourself.

- Tell us about the business start-ups you have been involved with.

- What and who influenced you when you were planning to start your business?

- What advice would you give others?

- Is there anything you would like to add to the discussion?

The prompts provided a necessary beacon during the interviews. Their primary purpose was to ensure we did not get swept away in interesting discussions that were well beyond the scope of our area of enquiry, although we respected participants' choice of topics. The interviews were largely informed by Kaupapa Māori principles and therefore the discussions evolved in accordance with the experiences and issues raised by each participant.

At the conclusion of each engagement, we demonstrated our appreciation to the participant for the time that they had allocated to our research through a koha. This small token is an important component of the participantresearcher engagement because it implies a shared commitment and an understanding of reciprocity and respect. The audio recordings of each interview were transcribed for the purpose of analysis. Participants received a copy of the transcription and were invited to critique, elaborate, add or remove any material they thought was not relevant or no longer felt comfortable sharing. The knowledge shared with us is explored and interpreted in the following section. 


\section{Exploring Māori entrepreneurs' talk about embeddedness}

This section presents five Māori entrepreneurs' perspectives on how they embed themselves, others and the work they do in certain environments. Selected accounts are taken from our five participants' transcripts, which we have chosen to refer to as Pūkōrero: Pūkōrero Tahi, Pūkōrero Rua, Pūkōrero Toru, Pūkōrero Whā and Pūkōrero Rima. By "Pūkōrero" we mean someone who has the authority to speak as an entrepreneur, someone who is an articulator of their profession, a spokesperson for themselves and their whānau, a narrator. It is Māori entrepreneurs-not governments or accountants or consumers-that are the decision-makers in the process of venture creation. The consequences of their actions, be they positive or negative, are experienced not just by the entrepreneur alone, but by those closest to them such as immediate whānau. With this responsibility, Māori entrepreneurs look to embed themselves in certain social processes in order to make sense of their entrepreneurial business realities. This was apparent in all our interviews.

From the knowledge gained through an analysis of the interview texts offered by our five Māori entrepreneurs, we argue in this section that embeddedness holds great potential, but that a re-articulation of how we interpret embeddedness is essential for future Māori entrepreneurship research. Our brief analysis is broken up into the four original constructs: migration, settlement, identity and business. We first discuss points of relevance and departure for each and then provide a revised model.

\section{The migration construct}

The migration construct asks whether the influences of home impact decision-making (de Vries et al., 2015). In the context of Dutch, Chinese, Indian and Pacific peoples, the original research considered "home" to be the original geographic nations from which they came to Aotearoa New Zealand. Unsurprisingly, the Māori entrepreneurs we interviewed narrated connections to whenua, whakapapa and whānau, but in different ways. Some had a strong and lifelong affiliation with their marae and a clear sense of identity and belonging to whenua and whakapapa as well as whānau. Others found they were still on a journey to achieving a strength of connection. Of course, engaging in Māoritanga was experienced in many ways. What has become apparent to us is that this migrant construct (albeit an unsuitable term, which we'll come to later) is useful for the purposes of analysing Māori entrepreneurial talk because it focuses our attention on the connections entrepreneurs make with "home" in all its possible manifestations.

For Pūkōrero Rua, the connection to culture was clear: "I grew up on my pā, so I've, I know every facet of every step, of every footprint, I know all the stories and I'm lucky to have that ...” Drawing on that strong connection, Pūkōrero Rua continued by contrasting his experience with others' in a way that suggests it sets him apart: “. . . and that's not a reality for many.” In a different fashion, Pūkōrero Whā revealed a connection to both Māori and Pākehā roots, or, more specifically, an iwi link as well as nation-state links. She also acknowledged her mother's migration from Scotland to Aotearoa:

On one side, I come from . . . Ngāi Tahu, grew up at the pā and worked in stock ... On the other side, my mum was from Scotland and she came over here when she was a teenager ... So that blend of Ngāi Tahu here ... and then first generation immigrant as well.

Pūkōrero Rima came from a family that moved around a lot; however, she recited exactly where each of her parents came from and the places of significance to her family growing up:

My father was a part of the ... urban shift and drift and obviously in terms of the trades... 
so we moved up the island as Dad went along the dams and we were born in those areas.

This is part of a powerful narrative linking people and place, but it also highlights the influence of industry and employment on whānau and intranational migration patterns. Pūkōrero Rima talked about the value of extended family creating a housing procurement plan to establish a whānau living arrangement, and about embedding roots in their chosen area of residence. She told us about having four houses next to each other with 21 whānau members living together and signifying the connection between whānau, whenua and whakapapa.

In contrast to these narratives, an excerpt from Pūkōrero Tahi's experience illustrates a disconnect with papa kāinga: "My marae is down the bottom of the South Island, I've never been there." However, Pūkōrero Tahi went on to reveal that his business served as a vehicle for establishing whānau connections based at his marae: "I've started working with the guy who runs the marae down there, so that's been cool. It's actually cool going through and seeing how we link up." Pūkōrero Toru's desires, meanwhile, contrasted with those of other whānau members: "I think it's that cultural experience that really grounded me. I really wanted to stay and others, you know, my brother especially was desperate to get out."

Those that did not have an upbringing on the pā, a connection with their marae or an understanding of their whakapapa found that they were somewhat disconnected from their home culture. There were no inferences to suggest that this was either an advantage or disadvantage; rather, and more interestingly, these entrepreneurs leveraged their ventures to create opportunities to reconnect. The migration construct is useful to measure the strength and therefore influence of kin, land and ancestry on the entrepreneurs. With the benefit of having explored the relevance of the migration construct empirically, we believe the notion of papa kāinga narratives would better help the researcher explore the accounts of Māori entrepreneurs for what they can reveal about the intricate influences of home culture on the entrepreneur-whatever "home" may be.

\section{The settlement construct}

The settlement construct explores the societal embeddedness of an EMG (de Vries et al., 2015). We acknowledge that the ripples of complex historic social, political, cultural and economic challenges have had varying impacts on Māori in the present context, such as loss of language, cultural practice and urban drift. Through our empirical work it was clear that, despite these challenges, entrepreneurs crossed paths with impactful people that encouraged personal and professional development and refined entrepreneurial behaviours at various stages of their entrepreneurial journey. In a similar fashion to our participants, we depart from discussing the problems arising from influences of the coloniser and instead opt for a solutioncentred approach. The settlement construct is useful in describing effective strategies for constructive social grooming. Through this construct we consider the influence of kin, friends, role models, teachers and complete outsiders on Māori entrepreneurship. In most cases those influential others helped to build a roadmap for turning aspiration into reality. Each "crossing of paths" could be termed a pivot point in the entrepreneur's life journey. These pivot points varied in length and intensity.

The crossing of paths of Pūkōrero Rua and his grandparents lasted all through high school and was highly intimate. At the other extreme, the crossing of paths of Pūkōrero Tahi with a minister was less than a day in length and distant (in a public setting). The construction of chronologies in narratives helps us understand the influences and connections between people. Despite the variation in time spent with these groups of people, both events appeared to impact on each of their lives immensely. 
Pūkōrero Tahi had always believed that being Māori was synonymous with being poor, and had assumed that this would be the reality for his future. A turning point was an inspired speech from a government minister and from there Pūkōrero Tahi set out to challenge the stereotype, including getting a degree and being the first in his family to do so. Making life-changing decisions to pursue personal and professional development laid the foundational skills for entrepreneurial endeavours later in life. Extended whānau were vital to encouraging his development:

Mum and them ... they finished school when they were 13,14 . So when [a cousin] was like, what are you doing after school, you should come do a bridging course so we can get you in at uni, I was like oh, yeah sweet, got nothing planned.

Pūkōrero Rua was equally influenced by whānau, which created a work ethic heavily guided by grandparents and aunties:

My grandfather would be up at 5:30, turn on the light and be like get up, you gotta do cleaning, put the washing on the line and um gotta do this and that before you have breakfast, and you gotta be on the bus at 7:30 a.m.

$\ldots$

My other mum's two aunties were selfemployed, one involved in Te Wananga o Aotearoa; that's how I went to Te Wananga. She kinda roped me in she said, "Here, try this." The other simply encouraged actionpushed me and said, like, um, "Just do it, stop talking about it."

Pūkōrero Rua's grandmother was a strong advocate for higher education and got each of her children through university. The value of his grandmother's expectations was maintained and became indelible: "She kinda engrained that in us." Parents too played a part in the narratives as they set minimum standards of success and promoted personal development: "Mum and Dad instilled about wanting to do well in education but also in terms of being able to work confidently in both worlds. Their expectations was to do better than them" (Pūkōrero Rima).

Pūkōrero Toru credited some friends he met doing a Māori studies degree who took him out to their marae: "They were really keen ... to bring me out to their respective marae... just really bring me into the fold ... It was that holistic experience of you know, getting a foothold into my culture that was really, you know massive." This positive experience with his culture instilled a personal motivation for language development and venture creation in an effort to improve his contributions to his culture. Upon venture creation, Pūkōrero Toru found a mentor whom he believed to be successful, which may have impacted on his perception of credibility and willingness to learn from him: "He's got his hands in lots of ventures ... he's been quite successful . . . he's all about numbers and margins." Pūkōrero Toru's wife was also an influence despite his natural risk aversion and resistance to some of her ideas: "While [my wife] was wanting to market, push it, I was almost you know, reluctant to do any of that and let's just, let's just stick with [the iwi]—that's nice and safe.

For Pūkōrero Whā, it was an Indigenous social entrepreneur who served as a highly relatable role model and encouraged action:

She resonated, so the first time I saw her was at some conference and she, she's a home girl with attitude doing just hearty stuff and really honest about who she is and so she was the first person I went, I feel like you feel and you do this and bugger it, I'm going to have a crack too.

It is apparent from these accounts that early influences play a lasting role in the motivations 
of Māori entrepreneurs. Once established, Pūkōrero Tahi described his desire to pay it forward and to inspire others: "I try and mentor anyone who wants to like know anything." The settlement construct, as we reinterpret it, has more relevance in the Māori entrepreneurship space when used to explore the impact of influential people on entrepreneurial decision-making. The narratives reproduced in this section show how hope, ambition, coercion and so on are enacted by significant others. As Māori entrepreneurs reflected on their experiences, they led us to uncover complex relationships which require further exploration than the surfacelevel accounts we have offered here. However, the notion of whakaaweawe narratives suggests a compelling starting point for researchers investigating the impact of social interactions on Māori entrepreneurial behaviour.

\section{The identity construct}

The identity construct describes the extent to which an entrepreneur embeds their business within either a collective (family or community) identity or individual identity. This construct may be best visualised as on a continuum, with individual aspirations at one end and collective objectives at the other. It is the movement along this continuum over time that offers some insight into how the business identity is embedded in the personal aspirations of the entrepreneur.

Each of our entrepreneurs started their narratives with aspirations to be independent from the constraints of working in an organisation, and to have greater ownership of decisions and flexibility to suit their lifestyle and family. Perhaps the most critical stage of venture creation was establishing financial independence and sustainability: "That first year was rocky ... how can we justify doing this? And we were pumping our own savings into it as well" (Pūkōrero Toru). Initially driven by prospects of autonomy, the resulting enterprise offered leverage for attending to greater social aspirations:
"My consulting business was a way of funding some time to work out what my social enterprise contribution was" (Pūkōrero Whā). From there, participants either used their business as a vehicle for giving back to, or mobilising resources for, family in the first instance. It seems there was a natural progression towards creating and acting on concepts and opportunities to help others in the community and beyond.

Some also narrated broader agendas and how they were determined to accomplish them. To illustrate, Pūkōrero Tahi, Pūkōrero Rua and Pūkōrero Toru, along with two other entrepreneurs in the area, had banded together to create a social enterprise that brings all of their skillsets together in an effort to create a product that will serve others. That they only work on this initiative in their spare time demonstrates a highly motivated shared social conscience: "It's all about social enterprise. We're not about, we don't want to make money off it. We want to be able to make more things that can help more people" (Pūkōrero Rua).

The intentions of our participants to empower themselves, their whānau and broader social groups and communities, either individually or collaboratively, through entrepreneurship, are clear:

Things that we've gotten from our business and stuff, we've been able to just put it back into our own family.

$\cdots$

There is no success if you only got, if you are only successful on your own. That's why it's real cool just bringing everyone in ... just trying to ... better people you can see that need that tautoko. (Pūkōrero Tahi)

It's no longer just about me learning what I can and about what I can do and pass it on and it just happens that I have a lot of talented cousins and my brother and sister ... for 
me it's about getting them to the next stage. (Pūkōrero Rua)

It was collaborative because . . she really has an interest in marketing... she saw the value in video, web video and sort of digital marketing ... she sort of had the vision before me. (Pūkōrero Toru)

In terms of our economy [it] is to grow our own and to, you know, support where we can. (Pūkōrero Rima)

Pūkōrero Rima's business has enabled her to collaborate with many other Māori businesses and numerous social enterprise initiatives. Her agenda is to support local communities, and to do so with integrity: "It's really important that we do the best we can because we will continue to see people in the communities that we live."

The identity construct stands out for us as a concept which has similar connotations to self-determination. As such we think Māori entrepreneurs are constructing rangatira narratives. These narratives story the intentions and determinations of the entrepreneur as they transition from pōtiki to rangatira. Rangatira in this context is a term that is linked to kinaccountability and is a state of entrepreneurial leadership that is acquired over time and experience. It is marked by a shift in focus from economic outcomes to include social and cultural outcomes. Rangatira narratives reveal what it is that the entrepreneur-as-narrator is seeking to accomplish in their entrepreneurial lives, and we believe our participants exemplify that drive and determination to seek a better future for people beyond themselves.

\section{The business construct}

The business construct "is how the individual agency factors of confidence, and other human and financial capitals, produce a business-ready orientation that can embed in the opportunity structure and spawn entrepreneurship" (de
Vries et al., 2015, p. 101). In the accounts authored by the Mãori entrepreneurs we engaged with, there were clear business-type narratives that were largely of a technical or technological nature. To kick-start their entrepreneurial activities, the participants had found ways to acquire the necessary expertise and tools; that is, material technologies played a part in the success of the enterprise:

He ended up dropping off but we still had all the gear and all the software.

My dad bought me a laptop on hire purchase ... lots of bootleg software at the beginning. (Pūkōrero Tahi)

My business doesn't require any outlay to make a product. I bought a computer. (Pūkōrero Whā)

Material technologies were not the only tech-like components in the narratives of our narrators. People who held the expertise to assist with technical or professional jobs (technocrats) were also sought, employed or contracted in to carry out particular operations, whether formally or informally. This involved accountants, most saliently:

We have an uncle who's an accountant ... he was really helpful. (Pūkōrero Toru)

My process was call my mates and find an accountant . (Pūkōrero Whā)

Where skill-sets were missing and calculated to be of worth to the business, whānau were encouraged to develop the necessary skills: "She [her cousin] came on as admin support for me ... I said to her . . . I'd like you to do accounting-that's the sort of skill-set we need in the business" (Pūkōrero Rima). In other instances where friends or acquaintances were capable 
and available to fill a particular skill shortage, they would be procured for the execution of business activities on a project-by-project basis: "What we do together is basically we just tag each other into each other's projects; that's the way we operate" (Pūkōrero Rua).

Kin of Māori entrepreneurs inherit a responsibility to their entrepreneurial whānau member and their business: "Obviously it's a whānau business, umm, so by whakapapa, they have to work for us" (Pūkōrero Rima). Pūkōrero Whā described her whānau reaction to her entrepreneurial behaviour as one of passive support, even when they did not fully understand the mechanics of self-employment: "My whānau has never actually understood what I do ... [They'd say,] 'Going off to do it without having an employer is ok, I don't really get that, I'm sure you'll be fine.'”

Entrepreneurs' ventures tended to grow organically as they fostered the up-skilling and development of teachable and motivated individuals with similar values: "She [ākonga] comes over and brings her laptop and she sits there and she's like learning and I'm teaching her then, now she works with me with doing some contracts" (Pūkōrero Tahi).

These accounts story the various influences of technology: the technologies used, technocrats employed or fostered, and technical expertise utilised. We believe the notion of hangaran narratives better describes these findings than the business construct. What follows is a condensed account of the four narratives defined in this research: papa käinga, whakaaweawe, rangatira and hangarau.

\section{A Māori framework for future theorising}

With regard to this research, we believe embeddedness constructs are best considered components of narration or storying. That is, as we listened to the voices of Màori entrepreneurs we heard narrated/storied accounts.
Treating the accounts as such helped us to look for instances, moments and events that have relevance to not only the narrator, but other characters or people in the stories. We believe that construct is too "hard" a term and that narratives or stories better describes the accounts of the Māori entrepreneurs interviewed for this study.

The stories that Māori entrepreneurs recite and maintain are privileged forms of language. They are socially produced interpretive devices through which Māori entrepreneurs represent themselves, both to themselves and to other selves (see Feldman, Skōlberg, Brown, \& Horner, 2004). As our participants narrated particular lived experiences, their narratives naturally embedded them in environments, influences, impacts and intentions that help us to understand their complex entrepreneurial and social lives. These have been categorised into the following four types of narratives:

1. Papa kāinga narratives. These accounts reveal the influences of home culture on the entrepreneur and are open to the prospect of multiple home influences and traditions.

2. Whakaaweawe narratives. These accounts reveal the impact of influential people on entrepreneurial decision-making and the events that impact on or encourage entrepreneurial behaviour.

3. Rangatira narratives. These narratives story the intentions and determinations of the entrepreneur and often display a desire to pursue outcomes beyond individual needs.

4. Hangarau narratives. These accounts story the various influences of technology: the technologies used, technocrats employed or fostered and technical expertise utilised in and by their enterprises.

These narratives are complementary. They weave together to form a fuller account of Māori entrepreneurship without speaking with finite authority for anyone or any group. We 
propose these four narratives as the foundation of a framework for further exploration by researchers. We acknowledge that the narratives identified here may not be the only types of accounts told by Māori entrepreneurs. We believe, however, that Māori entrepreneurship researchers will unlock unprecedented depth in their empirical studies if they utilise these narrative structures and maintain openness to uncovering new narratives. By "new narratives" we mean other meanings that Māori entrepreneurs attribute to their lives and the lives of others in an entrepreneurial context.

\section{Conclusion}

In this paper embeddedness constructs drawn from the EMG literature were applied to a small selection of in-depth narratives produced by five Māori entrepreneurs. The potential of analytical constructs for future Māori entrepreneurship research was explored and suggestions for relevant narratives were provided as a result. We have attempted to re-present a model of Māori entrepreneurial experience that considers the modern reality of the present-day social, economic and cultural environment in New Zealand. This model pays attention to Māori entrepreneurial behaviour that reflects our progress as a multicultural nation in light of complex historic social, political, cultural and economic challenges. Consequently, the modest contribution this paper makes is to the conversation on research methods, and in particular the available tools for analysis. Māori entrepreneurs' narratives are the cornerstone of this research and provide a much needed glimpse into entrepreneurial realities that add credibility to our contribution.

There are limitations in the processes we employed to complete this project. For instance, we took an EMG model as a starting point and worked our empirical material into it. As such, the model came a priori to participant voices, which is problematic for extensive empirical studies. Therefore, when using the analytical tool developed in this paper researchers should be open to the prospect of narratives that challenge, question and disrupt prevailing and accepted knowledges. The small number of participants and the single location from which they were recruited are limitations, but as this paper does not purport to be a definitive empirical study these reservations are mitigated.

One thing is quite clear to us: There is simply not enough analytical guidance for researchers in the field of Māori entrepreneurship for interpreting the social processes and environments that entrepreneurs embed themselves in and are influenced and impacted by. Models are useful only in so far as they act as a tool in the pursuit of knowledge and not as a pervasive instrument for the retrospective validation of knowledge. Neither this paper nor the original embeddedness model has sought to accomplish the latter.

\section{Glossary}

$\begin{array}{ll}\begin{array}{l}\text { ākonga } \\ \text { Aotearoa }\end{array} & \begin{array}{l}\text { learner, protégé } \\ \text { Māori name for New } \\ \text { Zealand; lit., "land } \\ \text { of the long white } \\ \text { cloud" } \\ \text { technology } \\ \text { extended kinship } \\ \text { group } \\ \text { hangarau }\end{array} \\ \begin{array}{l}\text { iwi } \\ \text { formal call } \\ \text { Karanga }\end{array} & \begin{array}{l}\text { Māori approach or } \\ \text { ideology } \\ \text { gift, offering } \\ \text { visitor } \\ \text { koha } \\ \text { manuwhiri } \\ \text { Māori }\end{array} \\ \text { Indigenous people of } \\ \text { Aōearoa } \\ \text { Māoritanga culture, } \\ \text { practices and } \\ \text { beliefs } \\ \text { community centre, } \\ \text { buildings and } \\ \text { meeting spaces }\end{array}$




\begin{tabular}{|c|c|}
\hline Māui & mythical demigod of \\
\hline mihimihi & $\begin{array}{l}\text { Polynesian legends } \\
\text { greeting }\end{array}$ \\
\hline Ngāi Tahu & $\begin{array}{l}\text { tribal group of } \\
\text { Aotearoa }\end{array}$ \\
\hline Ngātiwai & $\begin{array}{l}\text { tribal group of } \\
\text { Aotearoa }\end{array}$ \\
\hline pā & fortified village \\
\hline Pākehā & $\begin{array}{l}\text { New Zealander of } \\
\text { European descent }\end{array}$ \\
\hline papa kāinga & $\begin{array}{l}\text { original home, } \\
\text { communal Māori } \\
\text { land }\end{array}$ \\
\hline pōtiki & $\begin{array}{l}\text { young and } \\
\text { opportunistic } \\
\text { person }\end{array}$ \\
\hline pōwhiri & $\begin{array}{l}\text { formal welcome } \\
\text { ritual }\end{array}$ \\
\hline pūkōrero & orator \\
\hline rangatira & elder \\
\hline rima & five \\
\hline rua & two \\
\hline tahi & one \\
\hline Tainui & $\begin{array}{l}\text { tribal group of } \\
\text { Aotearoa }\end{array}$ \\
\hline tangata whenua & $\begin{array}{l}\text { people of the land, } \\
\text { Māori }\end{array}$ \\
\hline tautoko & support, advocate \\
\hline Te Ātiawa & $\begin{array}{l}\text { tribal group of } \\
\text { Aotearoa }\end{array}$ \\
\hline toru & three \\
\hline whā & five \\
\hline whakaaweawe & influence \\
\hline whakapapa & genealogy \\
\hline whakawhanaungatanga & $\begin{array}{l}\text { establishing } \\
\text { relationships }\end{array}$ \\
\hline whānau & family \\
\hline whenua & land \\
\hline
\end{tabular}

\section{References}

Ajzen, I. (1991). The theory of planned behaviour. Organizational Behaviour and Human Decision Processes, 50(2), 179-211. http://doi.org/cc3

Aldrich, H. E., \& Waldinger, R. (1990). Ethnicity and entrepreneurship. Annual Review of Sociology, 16(1), 111-135. http://doi.org/dt66p6

Bandura, A. (1982). Self-efficacy mechanism in human agency. American Psychologist, 37(2), 122-147. http://doi.org/dszsqm

Bandura, A. (1991). Social-cognitive theory of selfregulation. Organizational Behavior and Human Decision Processes, 50(2), 248-287. http://doi. org/b4rh2m

Barrett, G. A., Jones, T. P., McEvoy, D., \& McGoldrick, C. (2002). The economic embeddedness of immigrant enterprises in Britain. International Journal of Entrepreneurial Behavior \& Research, 8(1-2), 11-31. http://doi.org/bwxzrb

Basu, A., \& Altinay, E. (2002). The interaction between culture and entrepreneurship in London's immigration businesses. International Small Business Journal, 20(4), 371-393. http://doi.org/dqg4nk

Cain, T., \& Spoonley, P. (2013, April). Making it work: The mixed embeddedness of immigrant entrepreneurs in New Zealand. Retrieved from http://ftp.iza.org/dp7332.pdf

Clark, K., \& Drinkwater, S. (2010). Recent trends in minority ethnic entrepreneurship in Britain. International Small Business Journal, 28(2), 136-146. http://doi.org/bh42qd

De Vries, H. P., Hamilton, R., \& Voges, K. (2015). Antecedents of ethnic minority entrepreneurship in New Zealand: An inter-group comparison. Journal of Small Business Management, 51(Suppl. 1), S95-S114.

Duncan, I., Bollard, A., \& Yeabsley, J. (1997). New Zealand migration: Business related flows- their role in internationalisation. Wellington, New Zealand: New Zealand Institute of Economic Research.

Durie, M. (2003). Ngā kāhui pou: Launching Māori futures. Wellington, New Zealand: Huia.

Feldman, M. S., Skölberg, K., Brown, R. N., \& Horner, D. (2004). Making sense of stories: A rhetorical approach to narrative analysis. Journal of Public Administration Research and Theory, 14(2), 147-170. http://doi.org/d5cm8z

Granovetter, M. (1985). Economic action and social structure: The problem of embeddedness. American Journal of Sociology, 91(3), 481-510. http://doi.org/dbkm9k 
Henry, E. (2007). Kaupapa Maori entrepreneurship. In L.-P. Dana \& R. B. Anderson (Eds.), International handbook of research on indigenous entrepreneurship (pp. 536-548). Cheltenham, England: Edward Elgar. http://doi.org/cfqz

Henry, E., \& Pene, H. (2001). Kaupapa Maori: Locating indigenous ontology, epistemology and methodology in the academy. Organisation, 8(2), 234-242. http://doi.org/djbdkq

Hiebert, D. (2003). Canada: A false consensus. In R. Kloosterman \& J. Rath (Eds.), Immigrant entrepreneurs: Venturing abroad in the age of globalisation (pp. 39-60). Oxford, England: Berg.

Jones, T., \& Ram, M. (2007). Re-embedding the ethnic business agenda. Work, Employment and Society, 21(3), 439-457. http://doi.org/brjr2x

Keelan, T. J., \& Woods, C. (2006). Māuipreneur: Understanding Māori entrepreneurship. International Indigenous Journal of Entrepreneurship, Advancement, Strategy and Education, 2(2). Retrieved from http://www. indigenousjournal.com/IIJEASVolIIIss1Woods. pdf

Kloosterman, R. (2010). Matching opportunities with resources: A framework for analysing (migrant) entrepreneurship from a mixed embeddedness perspective. Entrepreneurship \& Regional Development, 22(2), 25-45. http://doi.org/ bw2p69

Kloosterman, R., Van de Leun, J., \& Rath, J. (1999). Mixed embeddedness: (In)formal economic activities and immigrant businesses in the Netherlands. International Journal of Urban and Regional Research, 23(2), 252-266. http:// doi.org/cr7rp4

Krippner, G., Granovetter, M., Block, F., Biggart, N., Beamish, T., Hsing, Y., ... O’Riain, S. (2004). Polanyi symposium: A conversation on embeddedness. Socio-Economic Review, 2(1), 109-135. http://doi.org/cxjtc9

Kuntz, J., Näswall, K., Beckingsale, A., \& Macfarlane, A. (2014). Capitalising on diversity: Espousal of Māori values in the workplace. Journal of Corporate Citizenship, 55, 102-122. http://doi. org/bd99

Light, I. (1979). Disadvantaged minorities in self-employment. International Journal of Comparative Sociology, 20(1-2), 31-45. http:// doi.org/bp2bvx

Light, I. H., \& Bonacich, E. (1988). Immigrant entrepreneurs: Koreans in Los Angeles, 1965-1982. Berkeley, CA: University of California Press.
Mataira, P. (2000). Nga kai arahi tuitui Maori: Maori entrepreneurship: The articulation of leadership and the dual constituency arrangements associated with Maori enterprise in a capitalist economy (Unpublished doctoral thesis). Massey University, Albany, New Zealand.

McClintock, K., Mellsop, G., Moeke-Maxwell, T., \& Merry, S. (2010). Pōwhiri process in mental health research. International Journal of Social Psychiatry, 58(1), 96-97. http://doi.org/db97xx Mills, C., \& Pawson, K. (2006). Enterprising talk: A case of selfconstruction. International Journal of Entrepreneurial Behavior \& Research, 12(6), 328-344. http://doi.org/dx36q5

Nicholson, J. D., \& Wong, Y.-Y. (2001). Culturally based differences in work beliefs. Management Research News, 24(5), 1-10. http://doi.org/ cgnhq7

North, N., \& Trlin, A. (2004). Immigrants in business: A study of self-employed immigrants and their businesses in New Zealand. New Settlers Programme Occasional Publication Series No. 10, Massey University, Palmerston North, New Zealand.

Pantouvakis, A. (2013). Travellers' behavioral intentions depending on their beliefs: An empirical study. International Journal of Quality and Service Sciences, 5(1), 4-18. http://doi.org/cfq2

Peters, N. (2002). Mixed embeddedness: Does it really explain immigrant enterprise in Western Australia (WA)? International Journal of Entrepreneurial Behavior \& Research, 8(1-2), 32-53. http://doi. org/db5gmf

Pio, E., \& Dana, L.-P. (2014). An empirical study of Indian entrepreneurs in Christchurch, New Zealand. International Journal of Entrepreneurship and Small Business, 22(1), 17-24. http://doi.org/cfq3

Ram, M. (1997). Ethnic minority enterprise: An overview and research agenda. International Journal of Entrepreneurial Behavior \& Research, 3(4), 149-156. http://doi.org/ccz372

Sanders, J. M., \& Nee, V. (1996). Immigrant selfemployment: The family as social capital and the value of human capital. American Sociological Review, 61(2), 231-249. http://doi.org/ftd3f5

Tapsell, P., \& Woods, C. (2008). Potikitanga: Indigenous entrepreneurship in a Māori context. Journal of Enterprising Communities: People and Places in the Global Economy, 2(3), 192203. http://doi.org/dsfmqx

Te Puni Kōkiri. (2010). Tirohanga ohanga mo Te Moana à Toi-Māori entrepreneurship in Te 
Moana $\bar{a}$ Toi and New Zealand for 2001 and 2006. Wellington, New Zealand: Author.

Virdee, S. (2006). "Race", employment and social change: A critique of current orthodoxies. Ethnic and Racial Studies, 29(4), 605-628. http://doi. org/c7wr5t

Wang, C. L., \& Altinay, L. (2012). Social embeddedness, entrepreneurial orientation and firm growth in ethnic minority small businesses in the UK. International Small Business Journal, 30(3), 3-23. http://doi.org/cfq4

Warriner, V. (2007). The importance of traditional Maori values for necessity and opportunity:
Maori entrepreneurs-iwi-based and individually owned. In L.-P. Dana \& R. B. Anderson (Eds.), International handbook of research on indigenous entrepreneurship (pp. 558-564). Cheltenham, England: Edward Elgar. http:// doi.org/cfq5

Yeabsley, J. (1997). Settling policy issues in migrant choice of settlement. Wellington, New Zealand: Institute of Economic Research.

Zhou, M. (2004). Revisiting ethnic entrepreneurship: Convergencies, controversies, and conceptual advancements. International Migration Review, 38(3), 1040-1074. http://doi.org/dbw2ch 